\title{
1 Cratonic basins and the Wilson Cycle: a perspective from 2 the Parnaíba Basin, Brazil.
}

3

4

5

6

7

8 9

10

11

\author{
M. C. Daly ${ }^{1 *}$, B. Tozer ${ }^{1}$ and A. B. Watts ${ }^{1}$
}

${ }^{1}$ Department of Earth Sciences, Oxford University, Oxford OX1 2AN, UK

*Corresponding author (e-mail: mike.daly@earth.ox.ac.uk)

Cratonic basins and the Wilson Cycle

\section{Abstract}

Cratonic basins may be considered an inherent component of the Wilson cycle, initiating after continental collision, craton and supercontinent development; and before rifting and continental break-up. They do not result directly from the horizontal plate motions characteristic of the Wilson Cycle, but from localised and long-lived, vertical subsidence. Covering over $10 \%$ of the world's continental crust, the majority of preserved cratonic basins initiated in the Early Paleozoic, after the formation of Gondwana and Laurentia. Recent investigation of the Parnaíba cratonic basin of Brazil reveals six features that characterize it, and potentially, cratonic basins generally: formation on thickened lithosphere $(>150 \mathrm{~km})$; a pronounced, basal unconformity; a sub-circular outline and large area of the order of $0.5 \times 10^{5}$ to $2 \times 10^{6} \mathrm{kms}^{2}$; long-lived (100-300 Ma), exponential tectonic subsidence of shallow marine and terrestrial sediments; no extensional strain features such as rift systems, crustal thinning or Moho elevation; a central, deep sourced, relative gravity anomaly high. These characteristics indicate basin initiation and development, simply by a thermally and mechanically driven, vertical subsidence of the lithosphere. The relaxation of a post-orogenic thermal and mechanical perturbation, after the continental collision phase of the Wilson cycle, appears the most likely driving mechanism. The source of that perturbation remains unclear. 
32 The Wilson Cycle describes the evolution of an ocean basin (Wilson 1966), 33 through continental rifting, ocean opening, oceanic subduction, arc and 34 continental collision and craton formation, all driven by the horizontal 35 movement of lithospheric plates. Each of these tectonic phases has been characterized geologically through the recognition of ophiolite belts, collisional orogens, rift systems and deformed passive margins (Dewey \& Bird 1970). These tectonic associations have enabled the interpretation of much of the worlds Phanerozoic and Proterozoic geology in terms of plate tectonics (Burke \& Dewey 1973, Dewey \& Burke 1973, Dewey 1982, Sengor 1984). The Wilson Cycle built on Wegener's (1929) contention that today's continents were derived from a single ancestral continent, Pangaea. The Atlantic closure proposed by Wilson (1966), a significant event in the formation of Pangaea, opened the possibility of earlier supercontinents by repetition of the Wilson Cycle through time. The notion of a supercontinent cycle developed from the periodicity in Precambrian isotope ages (Gastil 1960). Four such supercontinents are now considered to have existed Pangaea, Rodinia, Nuna and Kenorland (Evans et al. 2016).

Cratonic basins are significant features of continental geology, yet historically they are not included in the Wilson Cycle. They cover over 10\% of continental crust, and are arguably developed throughout much of geologic time. Their absence in the Wilson Cycle is in part a result of their enigmatic geodynamic origin, and the fact that they occur dominantly within continents, rather than on continental margins where the Wilson Cycle has left its greatest footprint. On the basis of recent, detailed, characterization of the Parnaíba basin of Brazil (Daly et al 2014, Tozer et al. 2016), we propose that the formation of cratonic basins be considered an inherent component of the Wilson cycle. In contrast to most other Wilson Cycle features, the formation of cratonic basins appears to be entirely a process of vertical tectonics. No significant local extension is apparent representing a preceding phase of lithospheric stretching or rift basin formation.

61 Equally orogenic loading and associated flexure is not a relevant formation 62 process either. 
64 Notwithstanding the uncertainty in their tectonic subsidence mechanism, 65 cratonic basins appear to initiate during a particular part of the Wilson Cycle, 66 after continent-continent collision and the formation of a large continental 67 landmass, and well before continental break-up. Both Gondwana and Laurentia 68 are particularly long-lived large landmasses (>400 Ma) and both have several 69 examples of basins that fit this mode. In this paper we use recent insights from 70 the Parnaíba cratonic basin of Brazil to outline some of the significant features of 71 cratonic basins. We then discuss these in the context of basin formation, 72 supercontinent formation and the connection of these large continental basins 73 with the Wilson Cycle.

\section{Characteristics of cratonic basins}

Cratonic basins have long been recognized as a distinct basin type due to their within-continent location in cratonic and intra-cratonic regions of thick lithosphere (Figure 1). Characteristically they occur as singular, sub-circular shaped basins with long lived subsidence histories (Sloss 1963), and an absence of significant, horizontal strain features such as rifts (Sleep 1971, Fowler and Nisbet 1985, Hanne et al 2004, Allen and Allen 2013). Their singularity and subcircular geometry is in marked contrast, to the linearity and thousand kilometer length of other common basin systems such as rifts, strike slip, passive margin and foreland basins (Roberts \& Bally 2012).

Cratonic basins often comprise more than one basin forming stratigraphic unit, with the cratonic sequences being only a part of the tectono-stratigraphic history of the basin. The unconformity bounded, "cratonic megasequence" that is identified with the cratonic phase is specifically what we are dealing with in this paper.

93 Recent geophysical characterization of the Parnaíba cratonic basin of Brazil 94 (Daly et al 2014, Tozer et al 2016) has emphasised six distinct features of 95 cratonic basins and their megasequences that appear to apply globally. We outline these characteristics briefly below. 
1. Formation upon thick lithosphere $(>\mathbf{1 5 0} \mathbf{k m})$. Figure 1 shows the location of 25 cratonic basins globally and their underlying lithospheric thickness as determined by Rayleigh wave tomography (Priestley and McKenzie 2013). It also shows the approximate age of their initiation.. The large majority of the basins rest on seismic lithosphere between 150 and $250 \mathrm{~km}$ thick. The singularity of the basins is occasionally disrupted by long-lived arches that segment once contiguous basins. This is so in North Africa where the smaller and adjacent Murzuq and Kufra cratonic basins appear to have been contiguous and rest on thinner lithosphere. This thinner lithosphere may be a

2. A sub-circular outline of the order of $0.5 \times 10^{5}$ to $2 \times 10^{6} \mathrm{sq} \mathrm{kms}$. Figure 1 and figure 2 show the large scale and characteristic equant or sub-circular feature of original accretion in a forearc setting (Holt et al 2014), or may also be a result of extensive, post cratonic basin tectonics and crust and lithospheric thinning due to Mesozoic basin formation (Selley 1997). shape of the cratonic basins as they are preserved today. Although believed to be generally a close approximation, today's basin outlines are rarely the original shape due to post cratonic basin deformation and erosion. This

3. An underlying, profound, regional unconformity. It appears that all cratonic basin megasequences are underlain by a profound, sub-planar erosional unconformity of basin wide extent. This is clearly seen on regional seismic data in the Parnaíba basin of Brazil (Figure 3) where the cratonic megasequence overlies a large planar unconformity of truncated Lower Paleozoic and Neoproterozoic metasediments and crystalline rocks (Daly et al 2014). The unconformity marks the planation of an earlier orogenic phase 
and/or cratonic crystalline surface. In the case of the Brazilian and sub-

131 Saharan African cratonic basins, the basement comprises Neoproterozoic to 132 Lower Paleozoic (Brasiliano and Pan African) orogens (Brito Neves et al 133 2014).

There are several implications of this pronounced basal unconformity. Firstly, that there was a period of regional elevation and planation to sea level prior to the onset of the subsidence forming the cratonic basin. Sea level being registered by the marine sediments of the cratonic megasequence. Secondly, the erosion associated with that planation may have removed a significant volume of material and the resulting crustal thinning is potentially a component in the initiation of the basin (McKenzie \& Priestly 2016). Finally, that the time encompassed in the formation of such a large regional feature is likely significant, and separates the subsidence driving mechanism from most

4. Long-lived, quasi-exponential, subsidence profiles of 200-300 Ma. The Parnaíba cratonic megasequence lasts from the Upper Ordovician to the end of the Triassic, a period of about $240 \mathrm{Ma}$. The sediments are generally shallow marine, becoming terrestrial towards the end of the basins life. Several hiatus characterise the stratigraphic sequence and enhance a very slow average rate of sediment accumulation of less than $15 \mathrm{~m} / \mathrm{Ma}$ for the life of the basin. Tozer et al (2016) have shown that the backstripped tectonic subsidence in the Parnaíba basin is generally exponential and is fast initially and slow later on. This form of subsidence profile, similar across a number of cratonic basins, is also similar in form to the subsidence of rift-type basins (Allen \& Armitage 2012). Also characteristic of the subsidence is an offlapping geometry of the stratigraphic sequences within the cratonic basin

5. No evidence of lithospheric stretching preceding subsidence. It has been proposed that cratonic basin formation is a result of protracted, low strain rate extension and consequent thermal relaxation (Allen and Armitage 2012). 
Allen \& Allen (2016) developed this idea and concluded that cratonic basins represent a low strain end member of conventional extensional rift basins. However, the crucial supportive evidence of the strain expected from this model appears to be missing. The Parnaíba basin is well imaged by regional deep reflection seismic (Daly et al. 2014) and a wealth of industry 2D and 3D reflection seismic data (De Castro et al. 2016, Porto et al. 2016). The seismic reflection data do not show an extensive rift system that records the strain preceding thermal relaxation of the Parnaíba basin. They do show localized, deformed, remnant basins interpreted as Cambrian in age, between large areas of Proterozoic crystalline basement (Porto et al. 2016). In addition, the current depth to the Moho shows no indication of elevation above the regional level of the Moho to the east and west, and therefore no thinning of the crust, with respect to the basin margins. Figure 3 shows the Parnaíba Moho slightly deeper than the flanks of the basin, an observation supported regionally by Luz et al (2016) from receiver function studies. Rather than subsiding due to crustal and lithospheric stretching, it appears the lithosphere has subsided due to a different mechanism of a purely vertical nature.

A similar situation is repeated in many, perhaps all, cratonic basins where authors have commented on the missing rift basins assumed to be required for their formation (Sleep et al. 1980, Allen and Allen 2012, Holt et al. 2014, McKenzie and Priestley 2016). However, a Precambrian rift interpretation of seismic reflection data has been used as evidence of extension preceding the formation of the Congo cratonic basin, (Crosby et al. 2010). The same seismic features have also been interpreted as indicating a compressional, preOrdovician, Pan African structuring of the Congo basin prior to cratonic basin formation (Daly et al. 1992, Linol et al. 2015). In conclusion, the missing rift system and undisturbed Moho appear to be a general characteristic of cratonic basins as they are increasingly well imaged, and lays open the issue of what has caused the thermal perturbation that has resulted in the exponential subsidence patterns widely observed. 
6. A mid-basin, deeply sourced, positive gravity anomaly. The approximate centre of the Parnaíba basin is characterized by a localised gravity anomaly "high" which is superimposed on a regional gravity anomaly "low". This high coincides with an area of mid-crustal reflectivity imaged by the regional seismic data (Daly et al. 2014). The anomaly has been modeled as an area of increased lower crustal density of $+185 \mathrm{~kg} \mathrm{~m}^{-3}$ (Tozer et al. 2016). This is interpreted as evidence for a lower crustal area of magmatic intrusion Similar dense bodies have been interpreted in the Amazon (Nunn \& Aires 1988), Congo (Downey \& Gurnis 2009) and Michigan (Nunn \& Sleep 1984) basins.

These characteristic geological features of cratonic basins are summarized in the sketch of figure 4. Although based on the Parnaíba basin, these features appear common, and perhaps characteristic, of all cratonic basin and their megasequences.

\section{Implications for the formation mechanism of cratonic basins}

A large number of driving mechanisms have been proposed for the subsidence of cratonic basins (Hartley \& Allen 1994). These can broadly be categorized as involving a thermal or density perturbation in the crust and lithosphere with subsequent relaxation and subsidence; or a stress related phenomena driven by surface stresses (Farrington et al. 2010 \& Cloeting et al, 1988). The density perturbation may be developed from lithospheric stretching and thermal relaxation (Armitage \& Allen 2010) or a deep thermal source (Kaminski \& Jaubert 2000). A recent proposal by McKenzie \& Priestley (2016) has suggested the creation of a thermal perturbation as a result of orogenic crustal thickening, re-equilibration of geotherms and then rapid erosion generating a thermal perturbation that then cools and drives the basin subsidence.

In Parnaíba, it appears the subsidence history has not been greatly affected by post depositional events and the subsidence curves resemble the post rift phase of extensional basin subsidence driven by post-rift thermal contraction 
229 (McKenzie 1978, Cochran 1981), albeit, with a longer thermal time constant due 230 to the thick lithosphere. Given this similarity, and the fact that cratonic basins 231 appear to form on thick (>150 km) lithosphere, Allen and Armitage, (2010) and 232 Crosby et al., (2010) have suggested cratonic basin subsidence is driven by 233 thermal contraction following extension. However, mapping of the Parnaíba 234 stratigraphic isopachs through time, at the scale of a stratigraphic group shows a 235 consistent sub-circular form, and not the strong linearity characteristic of rift 236 systems (Figure 2). These maps also demonstrate the off-lapping character of the 237 sedimentary fill as the basin area shrinks with time. Such off-lap is evident in 238 many cratonic basins, for example the Congo (Kadima et al. 2011), and Michigan 239 basins (Nunn and Sleep, 1984).

241 These geometrical considerations apart, the extension initiated thermal 242 subsidence model is also inconsistent with geophysical data that images a 243 lithosphere that shows no evidence of thinning. A crustal thickness of $40 \mathrm{~km}$, has 244 been derived from the Parnaíba 2D deep seismic reflection velocity model (Daly 245 et al. 2014), and a more accurate $42+/-1 \mathrm{~km}$, interpreted from wide angle 246 reflection data (Tozer et al. 2016). These estimates are generally thicker than 247 crust to the east and west of the basin (Luz et al 2015). They are also much 248 greater $(+/-5 \mathrm{~km})$ than that consistent with backstripping of Parnaíba 249 subsidence. Equally importantly, the absence of widespread, extensional strain 250 features such as rift basins in the basement of the Parnaíba basin is apparent 251 from both academic and industry seismic reflection data (De Oliviera \& Mohriak 252 2003, Daly et al. 2014, de Castro et al. 2016, Porto et al. 2016).

254 In the absence of lithospheric extension, an alternative basin driving mechanism 255 is required that creates a thermal perturbation and its subsequent relaxation. 256 This is a detailed and complex issue that is the subject of other papers in 257 preparation. 
262 As mentioned in the introduction, the Wilson Cycle is an integral part of the 263 formation and breakup of supercontinents through time. Continents largely 264 resist the process of subduction due to their relative buoyancy. Hence the 265 periodic aggregation of continents is an inevitable consequence of plate 266 tectonics. Meert (2012) proposed the definition of a supercontinent as a single 267 contiguous continent comprising more than $75 \%$ of extant continental landmass. 268 Evans et al (2016) outlined four such supercontinents through time, Pangaea, 269 Rodinia, Nuna and Kenorland, and defined the passage between them as a 270 supercontinent cycle with a characteristic periodicity of 500-700 Ma. However, 271 the definitions proposed excluded large landmasses such as Gondwana, 272 Laurentia and Eurasia, all of which have been and are, crucial influences in our 273 understanding of Earth's history. Evans et al (2016) recognized this 274 shortcoming, but also recognized the power of the simplicity of a small number 275 of supercontinental periods. They proposed an informal subset they labeled 276 "semi-supercontinents", to include large and long lived landmasses that were the 277 subsets of true supercontinents, such as Gondwana and Laurentia.

279 Figure 1 shows our best estimate of the age of initiation of the cratonic basins 280 outlined, based on the oldest known sediments of the associated cratonic 281 megasequence. It highlights pronounced Early Paleozoic cratonic basin initiation 282 in Gondwana and Laurentia. In Eurasia the extensive impact of Cenozoic 283 continental collision makes the identification of earlier cratonic megasequences 284 uncertain. The map also shows preserved remnants of Precambrian cratonic 285 basins in Australia, Africa and Canada.

287 The major Gondwana cratonic basins of Africa and South America initiated after 288 the Late Neoproterozoic/Cambrian Pan African and Brasiliano orogenesis in the 289 Cambro-Ordovician. The initiation of the Parnaíba, Amazon, Parana basins 290 (figure 1) are well constrained as initiating in the Latest Ordovician on the basis 291 of the oldest sediments above the regional unconformity (Vaz et al. 2007, Milani 292 \& Zalan 1999). 
294 The Congo, Taoudeni, Kufra and Murzuq cratonic basins (figure 1) are less 295 precisely constrained as being initiated during the Cambro-Ordovician. Seismic 296 reflection data, constrained by wells, show that the Congo and Parnaíba cratonic 297 sections unconformably overlie folded and thrust stratigraphic sections 298 deformed during the Pan African/Brasiliano orogenic events (Daly et al. 1992, 299 Kadima et al. 2011, Daly et al. 2014). A similar geometrical relationship is 300 described by Craig et al. (2009) throughout the cratonic basins of North Africa, 301 where a flat lying "cratonic" Cambro-Ordovician section unconformably overlies 302 a deformed, then peneplained Neoproterozoic folded section.

304 Gondwana crustal development through the Early Paleozoic is therefore 305 characterized by the formation of several, large, sub-circular basins of slow, long306 lived subsidence, developed on lithosphere deformed during the Brasiliano/Pan 307 African orogeny. The same Lower Paleozoic period exhibits no major rifting and 308 breakup events in central Gondwana. In Laurentia Sleep (2009) and Armitage 309 and Allen (2010) point out similar fundamental characteristics for the Williston, 310 Illinois and Michigan basins. Most, if not all, of these large sub-circular areas of 311 prolonged subsidence show no related extensional events immediately prior to 312 the cratonic basin phase of subsidence.

314 The pronounced grouping of ages in Gondwana occurs after the stabilization of 315 the collisional tectonics that created Gondwana through the Late 316 Neoproterozoic-Ordovician (650-500 Ma) Brasiliano/Pan African orogenic 317 period. The stabilized Gondwana then survived largely intact for the next $250 \mathrm{Ma}$ 318 before extensive break-up began in the Mesozoic. The observation of widespread 319 cratonic basin formation in Gondwana, soon after Brasiliano/Pan African 320 orogenesis and stabilization, places the formation of these basins firmly in the 321 cratonic, post-collision and pre-break-up phase of the Wilson Cycle. This period 322 is very long lived in Gondwana and Laurentia (>200Ma), but is much shorter in 323 Pangaea where final collision and break-up followed relatively quickly (<50 Ma).

325 Two geodynamic implications of these observations may be significant in the 326 origin of cratonic basins. Firstly, crustal thickening associated with the pre- 
ceding collisional orogeny and continental accretion, will have resulted in a major thermal perturbation in the thickened crust and lithosphere. McKenzie \&

329 Priestley (2016) have modeled the rapid erosion of equilibrated thickened crust

330 to create a thermal anomaly that cools and results in the subsidence we see as a 331 cratonic basin.

333 Secondly, the mantle's convective response to the assembly of a large continental 334 landmass like Gondwana over one or more subducted slabs, is likely to result in a 335 period of thermal insulation (Philips \& Coltice 2010) and a reorganization of the mantle convective system (Zhong et al 2007). The thermal consequences of this insulation and reorganization may have resulted in an early period of widespread plume activity with associated magmatic material that has intruded into the upper mantle or lower crust and created both the thermal and mechanical perturbation recorded in the Parnaíba and other Gondwana cratonic basins. Clearly, this connection to the accretion of a large continental landmass is unproven and difficult to test. However, the regional geodynamic context, the characteristics of basin subsidence outlined above and a significant gravity anomaly are all tangible data that support this interpretation.

These general observations of Gondwanan and Laurentian Paleozoic basins indicate that the initiation of cratonic basins preferentially occurs in the period post-continental collision and semi-supercontinent formation, and prior to the rifting and break-up processes of continental fragmentation (Figure 5). In

350 Gondwana this period, from the Ordovician to the Triassic, lasts approximately $351200 \mathrm{Ma}$, before significant rifting and the commencement of the break-up of 352 Gondwana. During that long, static period, Gondwana and Laurentia developed 353 most of the worlds preserved cratonic basins.

\section{Precambrian Cratonic basins}

357 In addition to the well preserved Phanerozoic cratonic basins, several 358 Proterozoic cratonic sedimentary basins occur in the geological record (Allen 359 and Allen, 2013), although preservation is usually poor and the available 
360 subsurface data sparse. However, basement terranes have also been argued to 361 provide evidence for cratonic basin formation processes, unrecognised due to 362 thick sediment overburden in Phanerozoic basins (e.g. Stel et al. 1993).

364 The Paleoproterozoic, Mporokoso Basin of eastern Zambia (Figure 1) is a 365 potential example of a remnant cratonic basin (Unrug, 1982). This triangular 366 shaped cratonic megasequence is up to $5 \mathrm{~km}$ thick, covers over 60,000 sq km and 367 consists of interbedded fluvial, aeolian and lacustrine quartz and arkosic arenites 368 and variegated siltstones. The edges of the basin are defined by later zones of 369 deformation and Cenozoic rifting, and the largely flat lying Paleoproterozoic 370 rocks sit unconformably on a Paleoproterozoic basement of schists, gneisses, 371 calc-alkaline granites and andesitic volcanics known as the Bangweulu craton 372 (Andersen \& Unrug 1984). The Mporokoso basin has no apparent rift precursor 373 indicative of crustal stretching and, size apart, does have the other 374 characteristics discussed above, including the apparently off-lapping 375 stratigraphy diagnostic of a viscoelastic weakening lithosphere (e.g. Watts et al. 376 2013). Temporally the development of the Mporokoso basin pot-dates the 377 formation of the Paleoproterozoic Kenorland supercontinent (Evans et al. 2016).

379 In Australia, the Officer, Amadeus and Ngalia basins of central Australia (Figure 380 1) contain sediments of Neoproterozoic age (ca. 820-780 Ma) (e.g. Lindsay and 381 Leven, 1996; Haddard et al., 2001). During this initial subsidence, these basins 382 appear to have formed a single basin called the Centralian basin (Walter et al., 383 1992) of comparable size to that of a typical Phanerozoic cratonic basin. 384 However, these basins have been later modified by several orogenic episodes 385 resulting in inversion, compartmentalisation and overprinting by foreland style 386 subsidence (e.g. Haddard et al., 2001). Hence, the initial Neoproterozoic 387 subsidence is not well understood, but appears to form late in the accretion of 388 the Rodinia superconinent and to have many of the characteristics of wellpreserved Phanerozoic cratonic basins.

391 Finally, Stel et al., (1993) inferred that Proterozoic sediments found in Southern 392 Finland are remnants of a former cratonic basin. Based on observations of the 
surrounding exposed basement geology, namely mafic dyke swarms and silicic

394 dykes and A-type granite batholiths, these authors also developed a model for 395 cratonic basin formation. They suggest that passive upwelling of asthenospheric 396 material leads to the melting of the lower lithosphere and emplacement of 397 basaltic melt at lower crustal levels with associated mafic dyke swarms. This in 398 turn generates silicic melts that migrate to upper crustal levels, thereby forming 399 the observed A-type granites and silicic dykes and leaving in the lower crust, 400 mafic intrusive material. Upon cooling and crystallization this becomes a buried 401 load thereby driving plate flexure and basin formation as seen in the cratonic 402 megasequences described above.

\section{Discussion}

405

406 Sloss (1963) developed the early perspectives on cratonic basins in North 407 America's Michigan basin. He pointed out the characteristic bowl shape, shallow 408 water to terrestrial sedimentation and long-lived character. He perceived them 409 as vertically subsiding areas in central continental locations. Sleep (1971) and 410 Sleep et al. (1980) developed largely thermally driven solutions for the 411 formation of the Michigan basin. Burke and Dewey (1973) suggested that 412 cratonic basins formed at the tips of rifts propagating into continental crust from 413 a divergent margin triple junction. However, the relevant cratonic basin is often 414 older than the propagating rift, perhaps suggesting a different relationship. 415 Armitage \& Allen (2010) argued that cratonic basins are initiated as the low 416 strain rate end-member of extensional type basins. They suggested that a low 417 strain rate, extended over a large time period, could explain the subsidence in 418 the Williston basin, although it's tectonic setting suggests a significant foreland 419 type contribution. They also acknowledged the absence of physical evidence for 420 the proposed rifting and lithospheric thinning. Far field stress (Cloetingh 1988) 421 and an upwelling plume (Middleton 1989) have also been proposed as viable 422 basin forming mechanisms. A dense load hypothesis has also been widely 423 argued, generated either by metamorphic phase changes (Haxby et al 1976) or 424 igneous intrusion and phase changes in the lower crust or lithospheric mantle 
425 (Fowler \& Nisbit 1985; Sousa, 1997). More recently McKenzie (2016) has

426 proposed an orogenic thickening, heating and unroofing model.

428 The well constrained geophysical and geological data set of the Parnaíba basin 429 makes some of these proposed subsidence mechanisms inapplicable or not 430 required to explain the evolution of this basin. In particular, there is no evidence 431 of extensional strain in the crust or mantle (Daly et al., 2014, Porto 2016) and the 432 gravity data is inconsistent with an eclogite phase change (Tozer et al. 2016). 433 However, the initiation of basin subsidence due to a visco-elastic weakening 434 response to a buried load, formed by a cooling igneous intrusion in the lower crust beneath the centre of the basin, does fit the data constraints. The orogenic unroofing model of McKenzie and Priestley (2016) may also be valid. However, it will require detailed $\mathrm{P} / \mathrm{T}$ paths from metamorphic data on the Parnaíba basement to test its applicability.

In the context of the Wilson cycle (Figure 5), our data and observations indicate that cratonic basin subsidence is a predominantly vertically driven tectonic process. Subsidence occurred on thickened lithosphere and developed above a major, post-orogenic unconformity. The subsidence continued for ca. $250 \mathrm{Ma}$ with a shallow, concave up, exponential form of decay.

The age of initiation groups the Gondwana cratonic basins of Africa and Brazil as post the Pan African/Brasiliano accretion of Western Gondwana (post $500 \mathrm{Ma}$ ).

448 The basins formed during a relatively stagnant period of the Gondwana supercontinent, $200 \mathrm{Ma}$ before it began to break up in the Permian. The Michigan, Illinois and Williston basins formed slightly earlier in a similar period of Laurentian continental stability.

453 The mantle processes active during periods of long lived super or semi454 supercontinental stagnation and the convective response have been modeled by 455 Zhong et al. (2007). They imply a period of increasingly active mantle plume 456 generation as the large continental lid prevents the cooling of particular parts of 457 the asthenosphere. This period of heightened plume activity may be the tectonic 
458 link to the origin of cratonic basins and their place in the Wilson cycle. The post459 orogenic, post-craton formation, supercontinent or semi-supercontinent phase 460 of crustal evolution favours a period of heightened mantle plume activity. At 461 least some of this activity may penetrate the lithosphere and result in the 462 formation of magmatic intrusions in the mantle and lower crust. The cooling of 463 this intrusion and thermal perturbation creates a dense load that initiates a 464 large, subsiding, sub-circular, cratonic basin.

465

\section{Conclusions}

467

468 The geophysical characterisation of the Parnaíba basin of Brazil has improved 469 the constraints on the formation of cratonic basins. These constraints are 470 consistent with much of the evidence-based literature on cratonic basins and can 471 be used to position these enigmatic basins within the Wilson Cycle. Specifically 472 we conclude that:

- The Parnaíba cratonic basin initiated in the Late Ordovician, about $50 \mathrm{Ma}$ after the accretion of Gondwana and the end of the Brasiliano and Pan African orogenic period (500 Ma). Gondwana remained intact for over 200 $\mathrm{Ma}$, and did not commence extensive continental rifting and break-up until the Mesozoic. This post-orogenic period, of a long-lived, stable, semisupercontinent, saw the proliferation of cratonic basins during the early

- The Parnaíba cratonic basin megasequence sits upon a major, post-orogenic, erosional unconformity of regional proportions. The basin developed over a long time frame (>200 Ma), and is characterized by very slow $(15 \mathrm{~m} / \mathrm{Ma}$ average), exponential subsidence. Sedimentation was dominantly shallow

- There is an absence of evidence, in such a well imaged basin, of widespread crustal thinning through extension and rifting, or a regionally elevated Moho. This negative evidence, together with the sub-circular isopachs of the 
491 stratigraphic Groups within the cratonic megasequence, lead us to believe that a process of continental extensional tectonics did not initiate the

493 Parnaíba basin.

495 - A relative gravity anomaly high over the centre of the Parnaíba basin, 496 coincident with an area of mid-crustal seismic reflectivity, suggests the 497 presence of an anomalously dense lower crust that may be associated with 498 the driving mechanism for the basin.

- A dense lower crust or upper mantle may have formed through magmatic or metamorphic processes. It's presence may have driven subsidence through viscoelastic relaxation and thermal contraction following plume activity beneath the large continental landmass.

- The prolonged existence of a stagnant to slow moving and long lived landmass of the scale of Gondwana or Laurentia, with a large area of

- Cratonic basins would therefore occur cyclically within the Wilson Cycle; post major orogenic periods and the formation of large landmasses that are long lived (>50 Ma); and before significant continental rifting and break-up. Whilst the driving mechanism of these basins is vertically, not horizontally driven, their context and generation appears deeply connected to the activity and sequence of the Wilson Cycle.

\section{Acknowledgements}

519 The authors would like to thank BP do Brasil and the Parnaíba Basin Analysis

520 Project (PBAP) partners for their support in this work. The seismic data 521 supporting this paper are owned by Global Geophysical Services Incorporated 522 (GGSI), 13927 South Gessner Road, Missouri City, TX 77489, USA. The data are proprietary to GGSI and are commercially available from them. The authors 
524 would like to thank Global Geophysical Services Inc., for their permission to 525 publish the profile discussed in this paper.

526

527 
Allen, P. A. and Allen, J. R. 2013. Basin Analysis: principles and application to

531 petroleum play assessment. Third Edition, Blackwell Publishing Ltd., Oxford, 532 549pp.

533

Allen, P. A. and Armitage, J. J. 2012. Cratonic basins. In: Tectonics of Sedimentary Basins: Recent Advances (ed. by C Busby and A. Azor) WileyBlackwell, 602-620, 647pp.

537

Andersen, L.S., Unrug, R., 1984. Geodynamic evolution of the Bangweulu block, 539 northern Zambia. Precambrian Research, 25, 187-212.

540

Armitage, J. J. and Allen, P. A. 2010 Cratonic basins and the long-term

542 subsidence history of continental interiors. Journal of the Geological Society, 167, 543 61-70.

544

Burke, K. and Dewey, J. D. 1973. Plume generated triple junctions: key 546 indicators in applying plate tectonics to old rocks. Journal of Geology, 81, 406547433.

548

Brito Neves, B. B., Fuck, A.F. and Pimentel, M. M. 2014. The Brasiliano Collage 550 in South America: a review. Brazilian Journal of Geology, 44(3), 493-518.

Cloetingh, S. 1988. Intraplate Stresses: A new element in Basin Analysis, in 553 New Perspectives in Basin Analysis, edited, pp. 205-230.

Cochran, J. R. 1981. Simple models of diffuse extension and the pre-seafloor 556 spreading development of the continental margin of the northwestern Gulf of 557 Alden, Proceedings of the 26th International Congress Symposium on Continental 558 Margins, Oceanologica Acta, 154-165.

560 Craig, J., Thurow, J.,Thusu, B., Whitham, A., and Abutarruma, Y. 2009. (eds) 
561 Global Neoproterozic Petroleum Systems: The Emerging Potential in North 562 Africa. Geological Society of London, Special Publications, 326, 1-25. DOI: $563 \quad 10.1144 /$ SP326.1

564

Crosby, A. G., Fishwick, S. and White N. 2010, Structure and evolution of the intracratonic Congo Basin, Geochemistry Geophysics Geosystems, 11, doi:10.1029/2009GC003014.

568

Daly, M. C., Lawrence, S. R., Diemu-Tshiband, K., \& Matouana, B. 1992. Tectonic evolution of the Cuvette Centrale, Zaire. Journal of the Geological Society, 149, 539-546. http://doi.org/10.1144/gsigs.149.4.0539

572

Daly, M. C., Andrade, V., Barousse, C. A., Costa, R., McDowell, K., Piggott, N. and 574 Poole. A. J. (2014), Brasiliano crustal structure and the tectonic setting of the

575 Parnaíba basin of NE Brazil: results of a deep seismic reflection profile, Tectonics, DOI: $10.1002 / 2014$ TC003632.

De Castro, D. L., Bezerra, F. H. R., Fuck, R. A. and Vidotti, R. M. 2016.

579 Geophysical evidence of pre-sag rifting and post-rifting fault reactivation in the Parnaíba basin, Brazil, Solid Earth Discussions, DOI:10.5194/se-2016-21.

581

De Oliveira, D C. and Mohriak, W. 2003. Jaibaras trough: an important element 583 in the early tectonic evolution of the Parnaíba interior sag basin, Northern Brazil. 584 Marine and Petroleum Geology, DOI:10.1016/S0264-8172(03)00044-8.

Dewey, J. F. 1982. Plate tectonics and the evidence of the British Isles. J, Geol. Soc. London, 139, 371-412.

588

Dewey, J. F. \& Bird, J. M. 1970. Mountain belts and the new global tectonics. Journal of Geophysical Research, 75, 2625-2647. reactivation: Products of continental collision. Journal of Geology, 81, 683-692. 
Downey, N. K. and Gurnis, M. 2009. Instantaneous dynamics of the cratonic Congo Basin. Journal of Geophysical Research, 114, B06401.

597

Evans, D. A. D., Li, Z. X. and Murphy, J. B. 2016. Four-dimensional context of

599 Earth's supercontinents. From: Li, Z .X., Evans, D A. D. \& Murphy, J. B. (eds) 2016.

600 Supercontinent Cycles Through Earth History. Geological Society, London, Special 601 Publication 424, 1-14. First published online March 2, 2016, 602 http://doi.org/10.1144/SP424.12

603

Farrington, R., Stegman, D., Moresi, L-N., Sandiford, M and May, D. 2010 605 Interactions of 3D mantle flow and continental lithosphere near passive margins. 606 Tectonophysics, 483, 20-28.

607 608 Fowler, C. M. R., and E. G. Nisbet 1985. The subsidence of the Williston basin, 609 Canadian Journal Earth Science, 22, 408-415.

610

Gastil, G. 1960. The distribution of mineral dates in time and space. American 612 Journal of Science, 258, 235-240.

613

Haddad, D., Watts, A. B. and Lindsay, J. 2001. Evolution of the intracratonic 615 Officer Basin, central Australia: implications from subsidence analysis and 616 gravity modeling. Basin Research, 13, 217-238.

Hanne, D., White, N., Butler, A. and Jones, S. 2004. Phanerozoic vertical motions of Hudson Bay. Canadian Journal of Earth Sciences, 41, 1181-1200.

Hartley, R. W. and Allen, P. A. 1994. Interior cratonic basins of Africa: relation to continental break-up and role of mantle convection. Basin Research, 6, 95-113. 

subsidence of accretionary orogens, Tectonophysics, 639, 132-143, 629 doi:10.1016/j.tecto.2014.11.021.

630

Kadima Kabongo, É., Ntabwoba, S. S. M. and Lucazeau, F. 2011. A Proterozoicrift origin for the structure and the evolution of the cratonic Congo basin, Earth 633 and Planetary Science Letters, 304, 240-250, doi:10.1016/j.epsl.2011.01.037.

634

Kaminski, E. and Jaupart, C. 2000. Lithosphere structure beneath the 636 Phanerozoic intracratonic basins of North America. Earth \& Planetary Science 637 Letters, 178, 139-149.

638

Lindsay, J. F., \& Leven, J. H. 1996. Evolution of a Neoproterozoic to Palaeozoic 640 641 intracratonic setting, Officer basin, South Australia. Basin Research, 8(4), 403642 643 424.

Linol, B., de Wit, M., Barton, E., Guillocheau, F., de Wit, M. C. J., and Colin, J-P. 645 Triassic 'Karoo-Like' Sequences of the Congo basin. In: M. J. de Wit et al. (eds.), 646 Geology and Resource Potential of the Congo Basin, Regional Geology Reviews, DOI: 647 10.1007/978-3-642-29482-2_7, C Springer-Verlag Berlin Heidelberg 2015.

Luz, R. M. N., Julia, J. and Nascimento, F. 2015. Crustal structure of the eastern 650 Borborema Province, NE Brazil, from the joint inversion of receiver functions 651 and surface wave dispersion: Implications for plateau uplift. J. Geophys. Res. Solid 652 Earth, 120, 3848-3869, doi:10.1002/2015JB011872 supercontinent. Gondwana Research, 21, 987-993. basins, Earth and Planetary Science Letters, 40, 25-32. 
660 McKenzie, D., and Priestley K. 2016. Speculations on the formation of cratons 661 and cratonic basins, Earth and Planetary Science Letters, 435, 94-104, 662 doi:10.1016/j.epsl.2015.12.010.

663

664

Middleton, M. 1989. A model for the formation of intracratonic sag basins, 665 Geophys. J. Int., 99, 665-676.

666

667

Milani, E. J. and Zalan, P. V. 1999. An outline of the geology and petroleum 668 systems of the Paleozoic interior basins of South America. Episodes, 22, 199-205.

669

670

Nunn, J. A., and Aires J. R. 1988. Gravity anomalies and Flexure of the 671 Lithosphere at the middle Amazon Basin, Brazil, J. Geophys. Res., 93, 415-428.

672

Nunn, J. A., \& Sleep, N. H. 1984. Thermal contraction and flexure of 674 intracratonal basins: a three-dimensional study of the Michigan basin. 675 Geophysical Journal International, $76(3)$, 587-635.

676 http://doi.org/10.1111/i.1365-246X.1984.tb01912.x

677

Philips, B. R. and Coltice, N. 2010. Temperature beneath continents as a 679 function of continental cover and convective wavelength. Journal of Geophysical 680 Research, 115, B04408.

681

682

Porto, A. L., Daly, M. C. and Fontes, S. L. 2016. The Pre-Silurian Riachão basin, a 683 new perspective into the Parnaíba cratonic basin, N E Brazil. (Abs.) 48 th 684 Congresso Brasiliero de Geologia, Porto Alegre, Brasil, Sociedade Brasileira de 685 Geologia, 2016. v. 1. código 5365.

686

Priestley, K., \& McKenzie, D. 2013. The relationship between shear wave 688 velocity, temperature, attenuation and viscosity in the shallow part of the 689 mantle. Earth and Planetary Science Letters, 381, 78-91. 690 http://doi.org/10.1016/j.epsl.2013.08.022 

of Geologic Analysis. Elsevier Science, ISBN: 9780444530424, 900 pp.

Selley, R. C. 1997. The basins of northwest Africa: structural evolution. In: African Basins: Sedimentary Basins of the World (Ed. R. C. Selley) Elsevier, Amsterdam, 17-26.

698

Şengör, A. M. C., 1984. The Cimmeride orogenic system and the tectonics of Eurasia. Geol. Soc. America Spec. Paper, 195.

701

Sousa, M. A. 1996. Regional gravity modeling and geohistory of the Parnaíba Basin (N.E. Brazil), Ph.D thesis, University of Newcastle, 107pp.

Sleep, N. H. 1971. Thermal effects of the formation of Atlantic continental margins by continental breakup, Geophys. J. Roy. Astr. Soc., 24, 325-350.

Sleep, N. H. 2009. Stagnant lid convection and the thermal subsidence of sedimentary basins with reference to Michigan, Geochemistry, Geophysics, Geosystems, 10, Q12015, doi:10.1029/2009GC002881.

Sleep, N., J. A. Nunn, and L. Chou 1980. Platform basins, Ann. Rev. Earth Planet. Sci, 8, 17-34.

Sloss, L. L. 1963. Sequences in the cratonic interior of North America. Geol. Soc. Amer. Bull., 74, 93-114.

Stel, H., Cloetingh, S., Heeremans, M. and van der_Beek, P. 1993. Anorogenic granites, magmatic underplating and the origin of intracratonic basins in a nonextensional setting, Tectonophysics, 226, 285-299.

Tozer, B., Watts, A. B. \& Daly, M. C. 2016. Gravity anomalies, seismic structure and subsidence history of the Parnaíba cratonic basin, northeast Brazil. Abs. American Geophysical Union, T32C-04. 
Unrug, R., 1984. The mid-Proterozoic Mporokoso Group of northern Zambia: 727 stratigraphy, sedimentation and regional position. Precambrian Research, 24, 99-121.

Vaz, P. T., Rezende, N. G. A. M. and Wanderley Filho, J. R. 2007. A Bacia do Parnaíba. Boletim de Geociências da Petrobras, Rio de Janeiro, 15 (2), 253-263.

732

Walter, M. R., Veevers, J. J., Calver, C. R., Grey, K., \& Hilyard, D. 1992. The 734 Proterozoic Centralian Superbasin: a frontier petroleum province. Bull. Am. Ass. 735 Petrol. Geol, 76, 1132.

736

Watts, A. B., Zhong, S. J., \& Hunter, J. 2013. The Behavior of the Lithosphere on

738 Seismic to Geologic Timescales. Annual Review of Earth and Planetary Sciences, 41(1), 443-468. http://doi.org/10.1146/annurev-earth-042711-105457

740

Wegener, A. 1929. The Origin of Continents and Oceans. (English translation by J. Biram, 1966) Dover Publications, New York.

Wilson, J. T. 1966. Did the Atlantic close and then reopen? Nature, 211, 676745 678.

746

Zhong, S., Zhang, N., Li, Z. X., and Roberts, J. H. 2007. Supercontinent cycles, 748 true polar wander, and very long wavelength mantle convection. Earth and 749 Planetary Science Letters, 261, 551-564.

750

751

752 
Figures:

755

756 Figure 1.

757 A world map showing lithospheric thickness after Priestley and McKenzie 758 (2013), together with the location of selected cratonic basins (basin outlines 759 after Torsvik, personal communication). The basins are coloured in line with the 760 approximate age of their initiation. Note the proliferation of basins forming soon 761 after the Cambrian stabilization of Gondwana and Laurentia..

762

763 Figure 2.

764 Isopach evolution of the Paleozoic lithostratigraphy of the Parnaíba cratonic 765 basin, shown at the lithostratigraphic "Group" level (as defined by Vaz et al. 766 2007). The three Groups make up the cratonic basin magasequence.

767 Inset map shows the geographic location of the Parnaíba basin in South America 768 and the position of the deep crustal seismic profile of figure 3.

769

$770 \quad$ Figure 3.

771 Parnaíba regional deep seismic reflection profile: (A) uninterpreted PSDM line;

772 (B) line drawing interpretation; (C) geoseismic interpretation overlaid on line 773 drawing (modified from Daly et al. 2014). The images show the scale and 774 tectonic setting of the Parnaíba basin and its basement structure.

775

776 Key: colours from east to west: Copper, Borborema Province basement; Orange 777 and Yellow, Parnaiba cratonic megasequences; Grey, Campo Maijor pull-apart 778 basin; Pink, Parnaíba basement; Green, zone of mid-crustal reflectivity; Mauve, 779 amphibolite facies metasediments; Brown, greenschist facies metsediments; 780 Purple, Amazonian craton.

782 Figure 4.

783 A geological and geophysical summary diagram of a 'typical' cratonic basin, 784 based on the Parnaíba basin, with key points numbered.

785 Key: 1. Lithosphere Asthenosphere boundary >150 km; 2. The Moho beneath the 786 cratonic basin shows a similar or greater crustal thickness to the flanks of the 
basin, indicating no significant crustal thinning during basin formation. 3. Preexisting continental crust largely hidden beneath the basin; 4. Pre-Silurian, deformed, remnant basins and small, late to post-tectonic Alkali granites possibly related to the emplacement of lower crustal igneous rocks prior to basin

791 formation; 5. Major crustal scale structure not reactivated during the deposition 792 of the cratonic megasequence, consistent with a purely vertical subsidence 793 model. 6. Regional, planar unconformity that underlies the entire basin; 7. Off794 lapping stratigraphic sequences of the cratonic megasequence; 8. Isolated, small 795 graben features preserving cratonic megasequence sediments beyond the 796 present outlines of the cratonic basin, indicating a much large footprint for the 797 original basin; 9. A markedly erosional edge to the basin indicating a much larger 798 footprint of the original basin.

\section{Figure 5.}

801 Sketch diagram showing cratonic basins in the Wilson cycle sequence.

802 1. Continental rifting: 2. Continental break-up, sea floor spreading and the onset 803 of oceanic subduction as an ocean basin is created and begins to be subducted; 3 . 804 Continental collision and lithospheric thickening builds a mountain range and 805 the subsequent onset of tectonic collapse, extrusion and erosion; 4. Stabilized 806 post orogenic crust, peneplained and restored to sea level with saucer shaped 807 subsidence defining the cratonic basin.

808

809 The cratonic basin is marked in yellow and develops between the continent 810 continent collision event, crustal thickening, tectonic collapse, erosion and 811 stabilization; and the onset of the next period of rifting and break-up (back to 812 sketch 1). In the case of Gondwana that time period, from collisional stabilization 813 to extensive break-up, was over $200 \mathrm{Ma}$.

815 Key: 1. Lithospheric mantle; 2. Oceanic crust; 3. Continent I; 4. Continent II; 5. 816 Continent III; 6. Syn-tectonic sediments; 7. Passive margin sedimentary wedge; 8. 817 Cratonic basins. 
820

821 


\section{Figures}

823

824 Figure 1

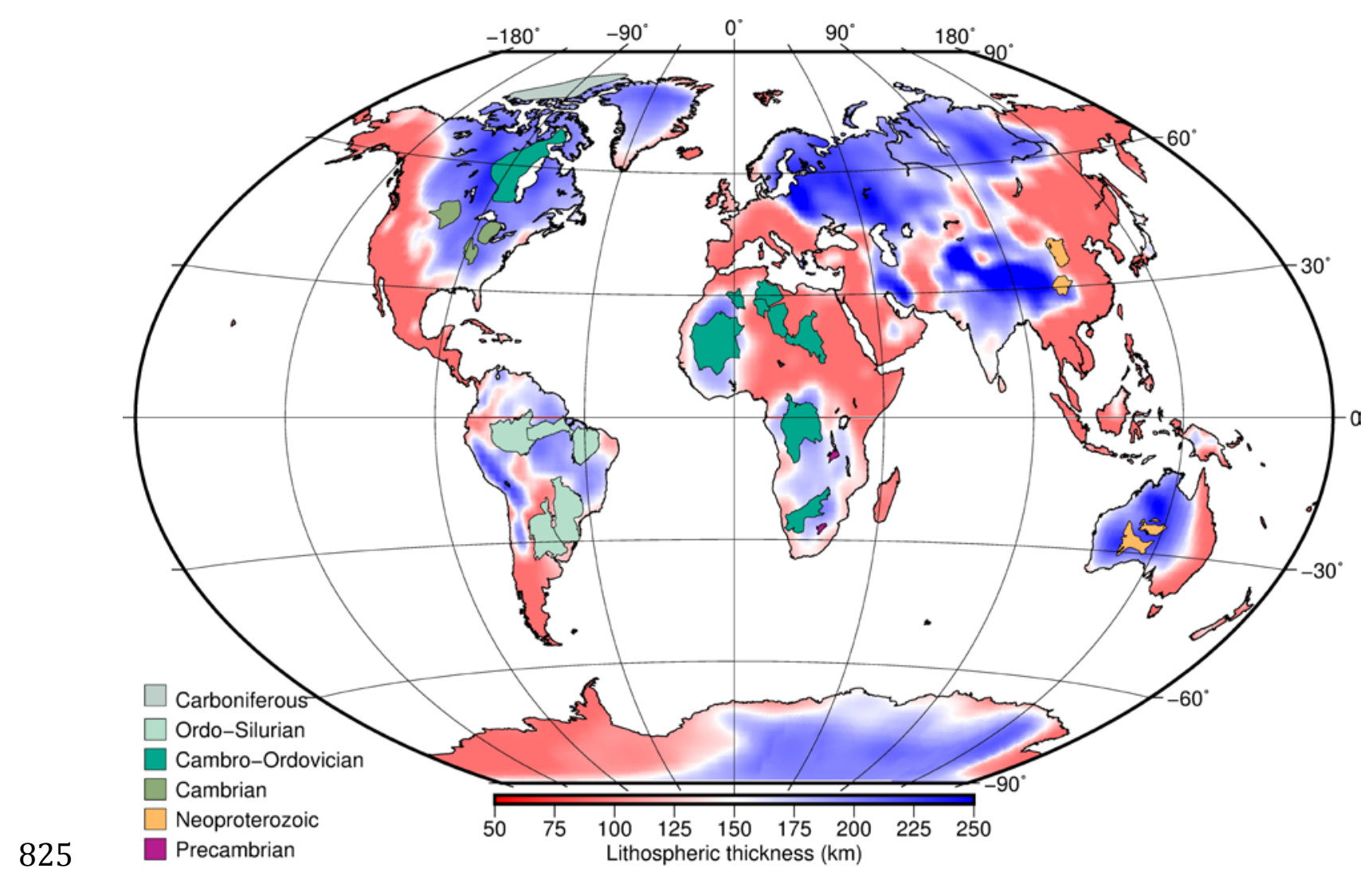

826 
Figure 2

Location Map

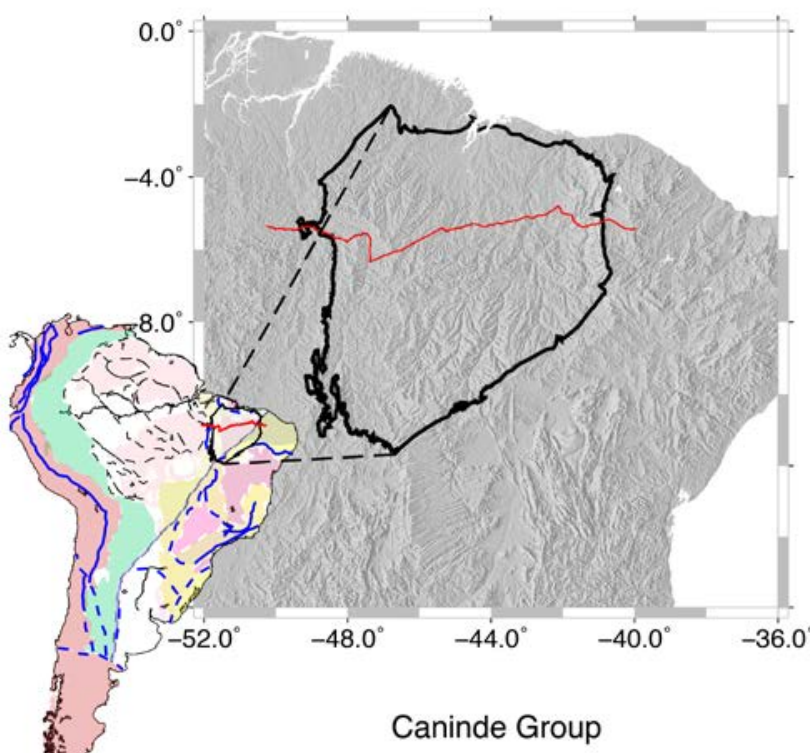

Serra Grande Group

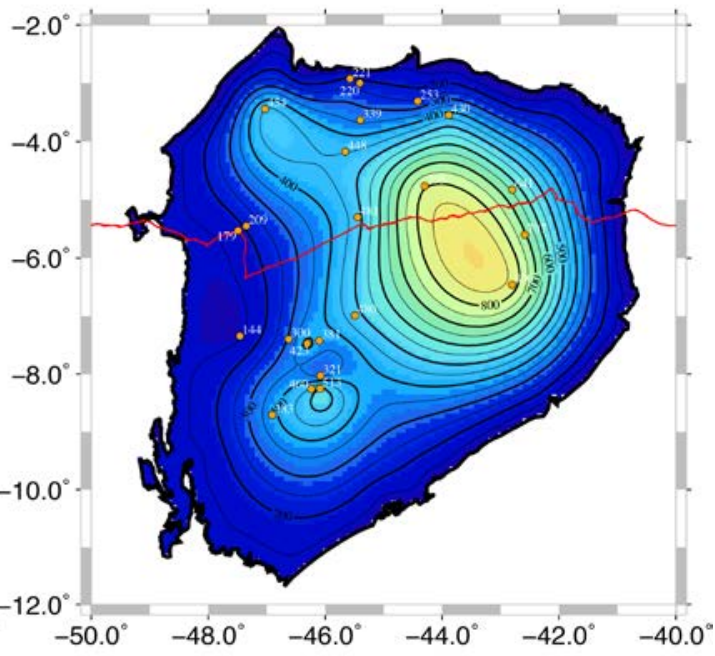

Balsas Group

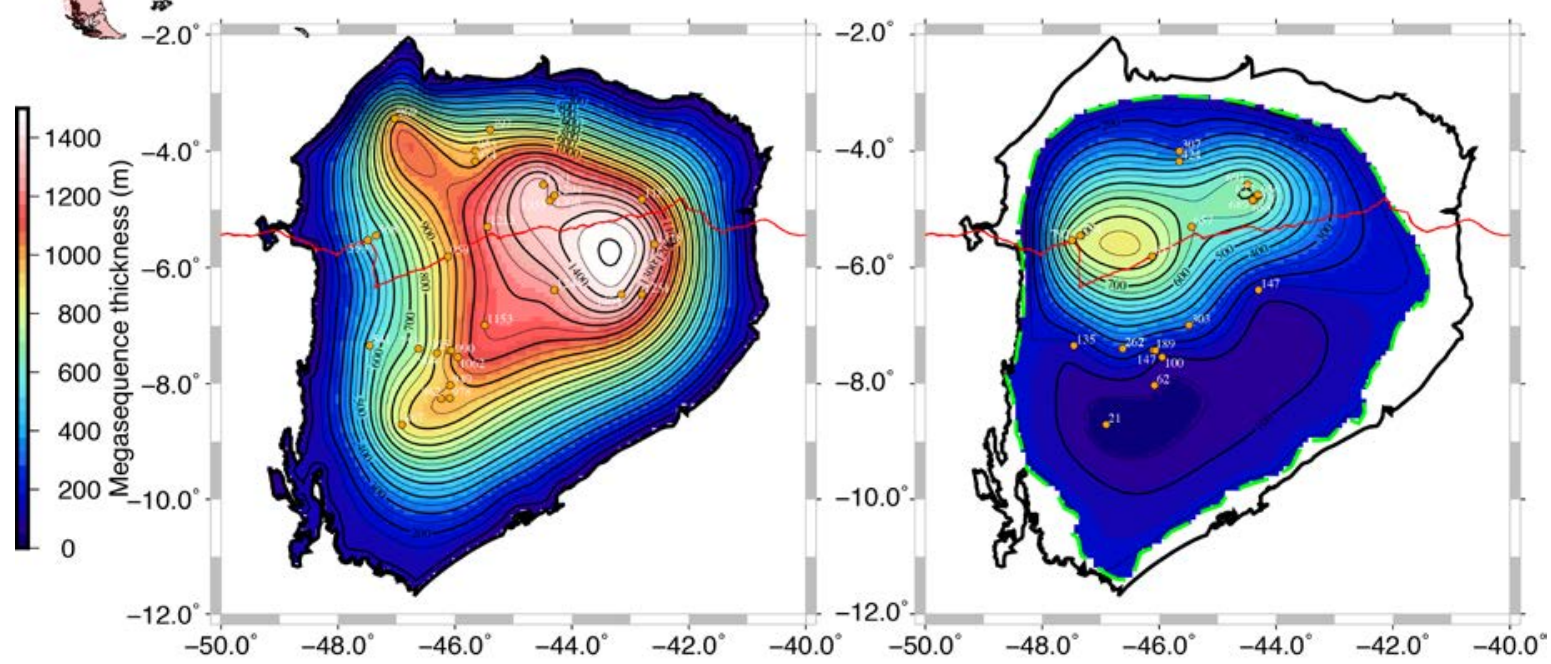

829 
Figure 3
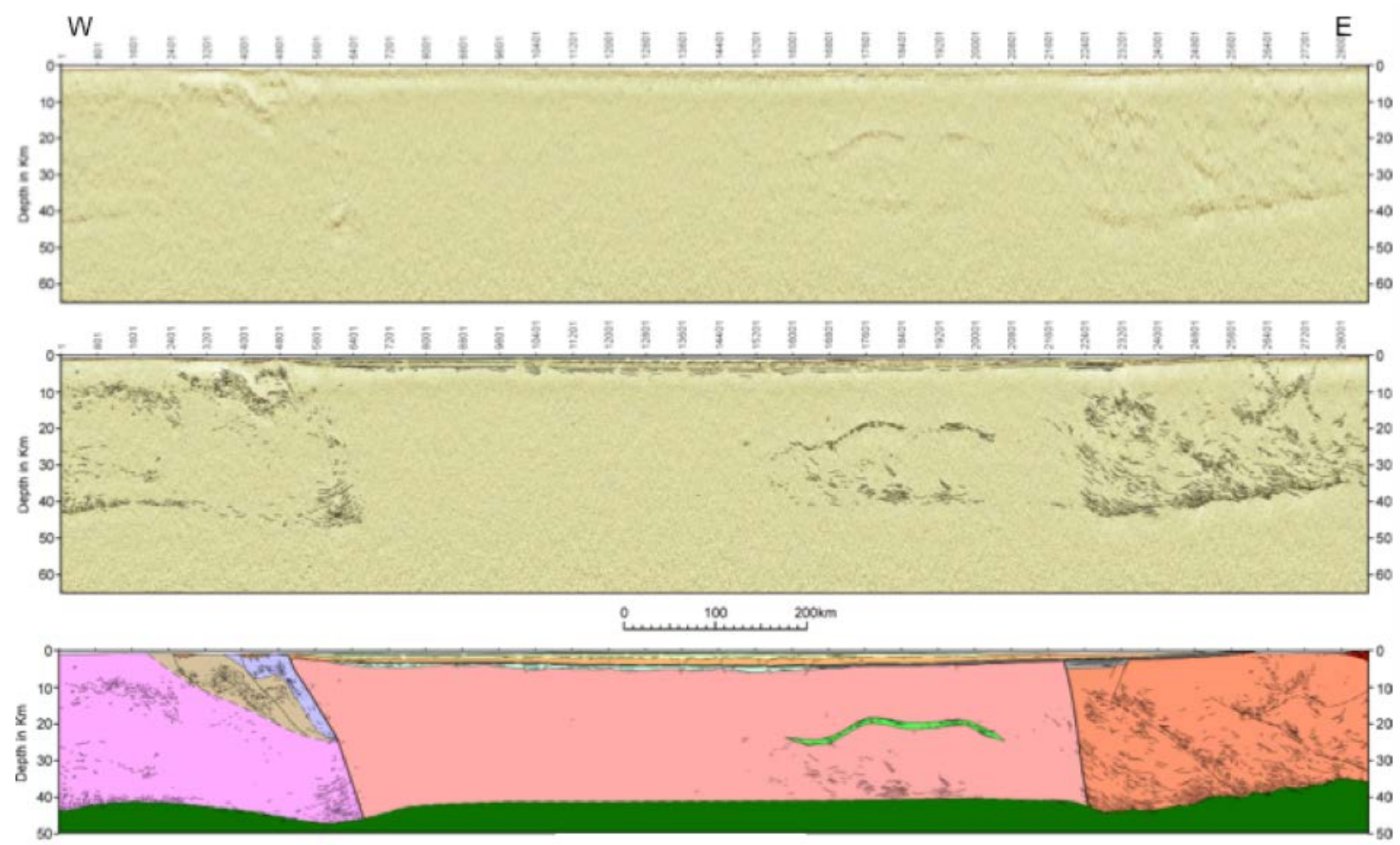

831

832

833 
$834 \quad$ Figure 4

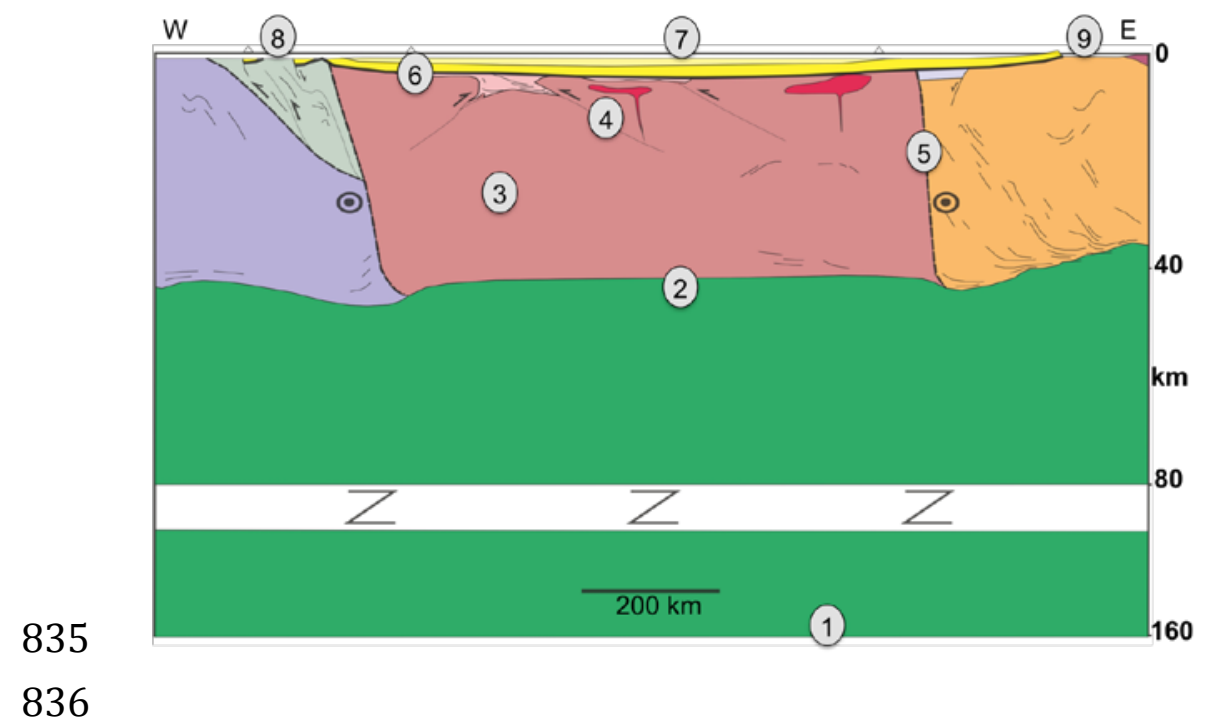


Figure 5
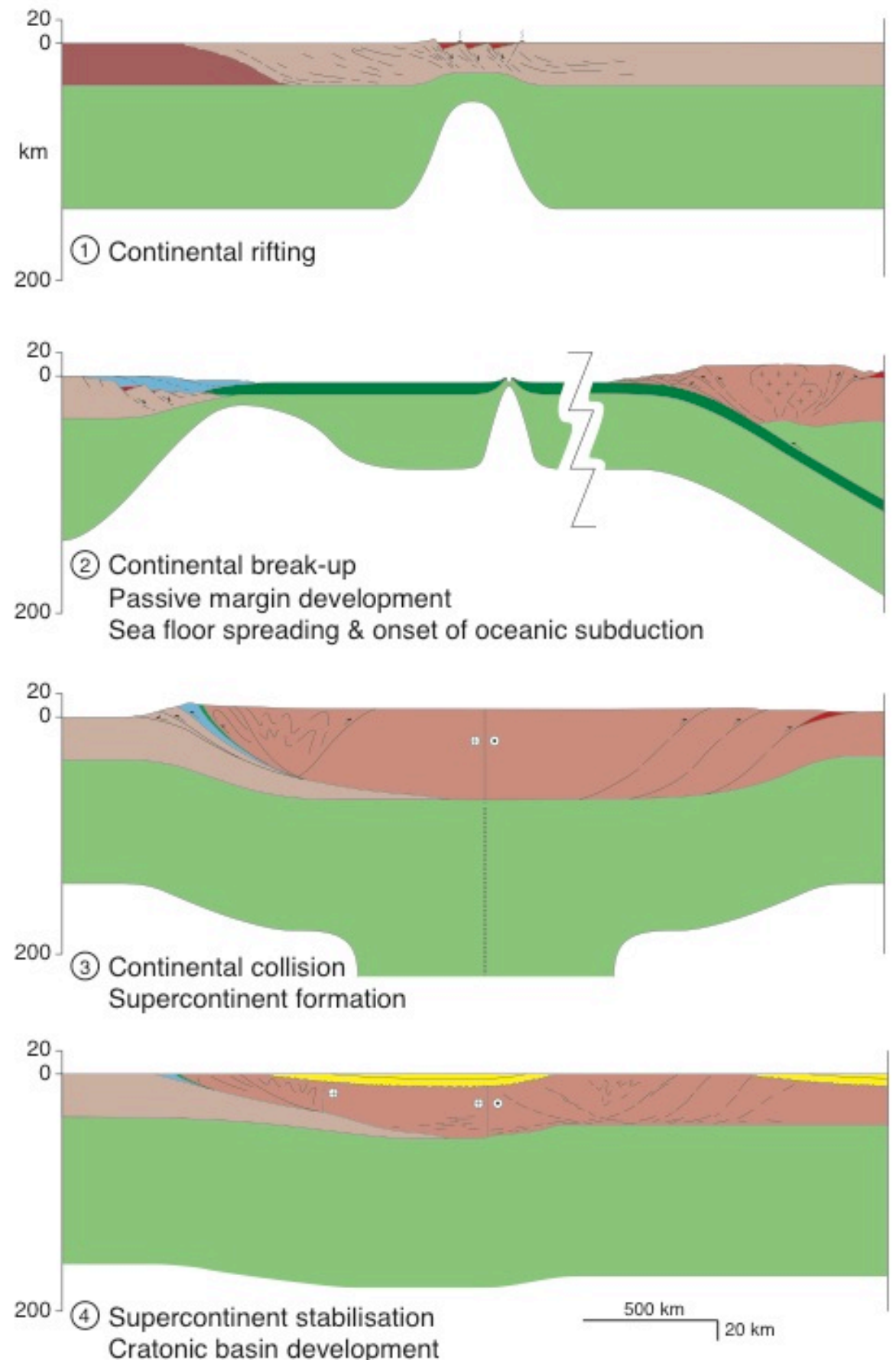

Cratonic basin development

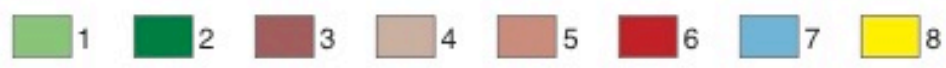

838 